\title{
Article/Artigo
}

\section{Accidents caused by Bothrops and Bothropoides in the State of Paraiba: epidemiological and clinical aspects}

\author{
Acidentes causados por serpentes dos gêneros Bothrops e Bothropoides no Estado da Paraíba: aspectos \\ clínicos e epidemiológicos
}

\section{Fagner Neves Oliveira ${ }^{1}$, Monalisa Taveira Brito ${ }^{2}$, Isabel Cristina Oliveira de Morais ${ }^{3}$, Sayonara Maria Lia Fook and Helder Neves de Albuquerque ${ }^{5,6}$}

\begin{abstract}
Introduction: Bothrops and Bothropoides snakes cause 70\% of the ophidic accidents in Brazil. The species that cause ophidic accidents in State of Paraíba are Bothropoides erythromelas, Bothrops leucurus and Bothropoides neuwiedi. Methods: This is a prospective and transverse study, following a quantitative approach of accidents involving Bothrops and Bothropoides admitted to the Toxicological Assistance and Information Centers of Campina Grande and João Pessoa (Ceatox-CG and Ceatox-JP), aimed at identifying the epidemiological and clinical profile of such accidents. All of the patients admitted had medical diagnoses and were monitored at Ceatox-CG or Ceatox-JP. Results: The genera Bothrops and Bothropoides caused $91.7 \%$ of the ophidic accidents reported. Snake bites were frequent in men $(75.1 \%)$, rural workers $(65.1 \%)$, literate individuals (69\%) between 11 and 20 years-old (21.7\%), and toes the most common area attacked $(52.7 \%)$. Most (86.6\%) patients were admitted within 6 hours after the accident/bite, with a predominance of mild cases $(64.6 \%)$. The annual occurrence in Paraíba was 5.5 accidents $/ 100,000$ inhabitants and lethality was $0.2 \%$. Conclusions: Positive changes in the profiles of these accidents were verified, such as the non-application of inadequate solutions, including the use of tourniquet, coffee grounds, garlic, suction and/or cutting the bitten area. Moreover, the Itinerant Laboratory project, linked to Paraíba State University in partnership with Ceatox-CG, has contributed positively, providing several cities of the state with information regarding the prevention of accidents involving venomous animals. The local press has also contributed, reporting the educational work developed by the centers.
\end{abstract}

Key-words: Bothrops. Bothropoides. Ophidic accident. Epidemiology. Serotherapy.

\section{RESUMO}

Introdução: As serpentes Bothrops e Bothropoides são responsáveis por 70\% dos acidentes ofídicos ocorridos no Brasil. As espécies causadoras de acidentes na Paraíba são Bothropoides erythromelas, Bothrops leucurus e Bothropoides neuwiedi. Métodos: Tratou-se de um estudo prospectivo e transversal, com abordagem quantitativa dos acidentes botrópicos e botropóidicos atendidos e registrados pelos Centros de Assistência e Informação Toxicológica de Campina Grande e João Pessoa (Ceatox-CG e Ceatox-JP), com o objetivo de conhecer o perfil epidemiológico e clínico deste agravo. Todos os pacientes atendidos tiveram diagnóstico médico e acompanhamento pelos Ceatox CG e JP. Resultados: Os gêneros Bothrops e Bothropoides foram responsáveis por $91,7 \%$ dos acidentes ofídicos notificados. Atingindo frequentemente o sexo masculino $(75,1 \%)$, trabalhadores rurais $(65,1 \%)$, alfabetizados $(69 \%)$ e na faixa etária entre 11 a 20 anos $(21,7 \%)$, os dedos dos pés foram as regiões anatômicas mais acometidas $(52,7 \%)$. A maioria $(86,6 \%)$ dos pacientes foi atendida em até 6 horas após o acidente/picada com predominância de casos leves $(64,6 \%)$. A incidência anual no estado foi 5,5 acidentes/ 100.000 habitantes e a letalidade $0,2 \%$. Conclusões: Verificaram-se mudanças positivas no perfil desses acidentes, como a não utilização de medidas consideradas inadequadas (uso de torniquetes, borra de café, alho, incisão com sucção e outras). Além disso, o projeto Laboratório Itinerante, ligado a Universidade Estadual da Paraíba em parceria com o Ceatox-CG, tem contribuído positivamente, levando a várias cidades do estado informações sobre prevenção e tratamento dos acidentes causados por animais peçonhentos. A imprensa local também tem contribuído, divulgando esse trabalho educativo.

Palavras-chaves: Bothrops. Bothropoides. Acidente ofídico. Epidemiologia. Soroterapia.

1. Health Sciences Graduate Program, Universidade de Brasília, Brasília, DF, Brazil. 2. Natural Products and Bioactive Synthetics Graduate Program, Universidade Federal da Paraíba,João Pessoa, PB, Brazil. 3. Pharmacology Graduate Program, Universidade Federal do Ceará, Fortaleza, CE, Brazil. 4. Pharmacy Departement, Universidade Estadual da Paraíba, João Pessoa, PB, Brazil. 5. Centro de Atendimento Toxicológico, Campina Grande, PB. 6. Agronomy Graduate Program, Universidade Federal da Paraíba, João Pessoa, PB, Brazil. Address to: Dr. Fagner Neves Oliveira. PPGCS/UnB. CLN Q. 413 Bloco A Asa Norte, 70876-510 Brasilia, DF, Brazil. Phone: $55618174-7599$.

e-mail: fagnerbiologo@gmail.com

Received in 06/04/2010

Accepted in 16/09/2010

\section{INTRODUCTION}

In Brazil, about 27,000 ophidic accidents were reported in 2008, in which Bothrops and Bothropoides snakes were responsible for about $70 \%$ of cases ${ }^{1}$. In the State of Paraíba, 1,098 (46\%) of the accidents caused by Bothrops snakes were reported between 1995 and $2003^{2,3}$. Bothrops and Bothropoides snakes are common and have a broad geographic distribution in several regions of the country. The species found in the State of Paraíba are Bothropoides erytromelas, Bothrops leucurus and Bothropoides neuwiedi ${ }^{2,4,5}$.

Bothrops venom has three main actions: 1) proteolyticornecrotic, which determinesinflammatory edema in the bitten area; 2) coagulative, which acts via one or more actions, such as thrombin-like (similar to thrombin action), activating the prothrombin and $\mathrm{x}$ factor, causing the consumption of coagulation factors and, consequently, altering blood coagulation; 3) hemorrhagic, which acts in the vascular endothelium of the bitten area and, probably, also at more distant sites, besides possessing certain other activities that can constitute part of the physiopathology of envenomation, such as fibrinogenolytic, fibrinolytic and platelet aggregator activity ${ }^{6-11}$.

Recently, considering the paraphyletism of Bothrops, morphological and molecular data suggested the creation of a new taxon to reclassify certain species formerly belonging to the genus Bothrops, this taxon was named Bothropoides and contains 11 known species: Bothropoides alcatraz, Bothropoides diporus, Bothropoides erythromelas, Bothropoides insularis, Bothropoides jararaca, Bothropoides lutzi, Bothropoides marmoratus, Bothropoides mattogrossensis, Bothropoides neuwiedi, Bothropoides pauloensis and Bothropoides pubescens ${ }^{5}$. This new classification is now generally accepted and is provided by the Brazilian Society of Herpetology ${ }^{4}$.

Further studies may clarify differences between the venoms of these two genera, which may even lead to the production of antivenom to neutralize the toxins of this taxon ${ }^{5}$.

According to data obtained from the National Network of Information Centers and Toxicological 
Assistance, Ministry of Health (Rede Nacional de Centros de Informação e Assistência Toxicológica, RENACIAT/MH), accidents caused by venomous animals were considered as the second major cause of human envenoming in Brazil ${ }^{12}$.

Research in specific regions presenting the local characteristics of this type of accident is very important. The objective of this research was to detect the clinical-epidemiological characteristics of accidents caused by Bothrops and Bothropoides reported at and admitted to the Toxicological Assistance and Information Centers of Paraíba, bearing in mind the fact that such centers are reference for the admittance of venomous accidents in Paraíba.

\section{METHODS}

A prospective and transverse study was conducted, following a quantitative approach of the epidemiological and clinical characteristics of all the cases diagnosed as bothropic or bothropoidic that were reported, admitted and monitored up to final evolution in the two Toxicological Assistance and Information Centers of Paraíba (Ceatox). One is located in the state capital, João Pessoa (CeatoxJP), a coastal city and the other in the city of Campina Grande (Ceatox-CG), located at an altitude of approximately $550 \mathrm{~m}$ above sea level, in the Eastern Borborema Plateau, $130 \mathrm{~km}$ west of the state capital. The Ceatox-JP is located at the Lauro Wanderley University Hospital and Ceatox-GC at the Dom Luiz Gonzaga Fernandes Regional Hospital in Campina Grande. Reports of occurrences and lethality for Paraíba referring to the period studied were calculated using population demographic data available at the IBGE (Brazilian Institute of Geography and Statistics) ${ }^{13}$.

The standardized record sheets used to collect these data were the ones of the National System of Toxic-Pharmacological Information (SINITOX) and of the National System of Notifiable Diseases (SINAN), Ministry of Health.

The epidemiological aspects of the ophidic accidents were evaluated taking into account two categories: variables related to the person (age, sex, occupation and education), and variables related to the accident (seasonality, area of occurrence, town, circumstances of the accident and anatomical area attacked).

Clinical findings were evaluated regarding the variables related to the accident and the variables related to attendance. For this study, the case was considered not an envenoming when the absence of symptoms was observed, including no changes in the physical examination and blood clotting time and/or by identification of the snake, recognized as non-venomous.

Regarding the variables related to the accident, the species of snake was definitively confirmed when the victim brought the snake and it was identified by a specialist; and it was considered as probable when it was not possible to identify the snake and diagnoses were determined by the clinical symptoms. Concerning the severity, the accidents were classified as mild, moderate and severe. In relation to the variables related to the treatment, the period between the accident and the admission to hospital was analyzed, as well as the serotherapy used; any complementary serotherapy, and any medication administered before serotherapy. The period the patient remained hospitalized and their clinical evolution were also analyzed.

Treatment before coming to hospital was considered adequate when one or more of the following steps were taken: cleaning the area with water or with soap and water, the patient was lying down and/ or drinking water, the animal was brought to be identified and the person was taken immediately to a hospital. Inadequate procedures included: using tourniquet, suction and/or cutting the bitten area, use of contaminated objects and the patient drank alcoholic drinks or teas.

Analyses were performed using the Analysis of Variance Test (one-way ANOVA), the Chi square test for linear tendency, Yates correction for continuity, whenever necessary, and the Fisher exact test. The level of significance of the tests used was established as 5\%, using the Epi Info version 3.4 (2007).

\section{Ethical}

The investigation was submitted and approved by the Ethics in Research Committee of the State University of Paraíba, protocol number 0063.0.119.000-07.

\section{RESULTS}

Between the years 2006 and 2008, the Toxicological Assistance and Information Centers of Paraíba reported and/or admitted 714 poisonous accidents, 447 caused by snakes considered venomous. Among the 447 notifications/admissions, 410 (91.7\%) were accidents caused by Bothrops and Bothropoides, with a mean annual occurrence of 5.5 bothropic and bothropoidic accidents per 100,000 inhabitants. Only 35 (8.5\%) of the cases confirmed the identification of the snake causing the accident, all of which were identified as the Bothropoides erythromelas specimen, and 5 accidents not presenting clinic symptoms considered as dry bites ${ }^{4}$.

In the cases analyzed, the patients were predominantly male (75.1\%), between the ages of 11 and 20 years-old $(21.7 \%)$, with a mean age of 34.6 years-old $(\mathrm{SD} \pm 18.9)$, rural workers $(65.1 \%)$ and literate individuals (69\%).

Accidents caused by Bothrops and Bothropoides in the State of Paraíba occurred mostly during the raining period of the years mentioned above. In 2006, such accidents were more common between July and August, while in 2007, they occurred more frequently between May and June, and in 2008, in April (Figure 1).

The accidents occurred in 74 small towns in the State of Paraíba. The towns with greatest number of reports of bothropic and bothropoidic accidents were: Taperoá, with 32 (7.8\%) cases; Boqueirão, with 27 (6.6\%); Juazeirinho, with 22 (5.4\%); Pocinhos, with 21 (5.1\%); Gado Bravo, with 17 (4.1\%); Barra de Santana, Cabaceiras and Campina Grande, with 16 (3.9\%) cases each; Soledade, with 14 (3.4\%); and Santo André, with 13 (3.2\%) cases. The other towns presented an index lower than $3 \%$.

A high proportion of bites were observed on the feet (52.7\%) in workers from rural areas (64.4\%), as show in Table 1. The average length of time, in hours, between the accident and hospital admission was $4.3 \mathrm{~h}(\mathrm{SD} \pm 6.5)$ for mild cases; $7.7 \mathrm{~h}(\mathrm{SD} \pm 16.9)$ for moderate cases; $12.3 \mathrm{~h}(\mathrm{SD} \pm 14.4)$ for severe cases. This correlation was statistically significant $(\mathrm{p}<0.01)$.

Inadequate treatment of ophidic accidents in this region of the country before clinical treatment was 19\% (Table 1). The use of a tourniquet was the most (25.6\%) frequent treatment error, pinhão roxo (Jatropha gossypiifolia) latex on the bite area and/or drinking the 


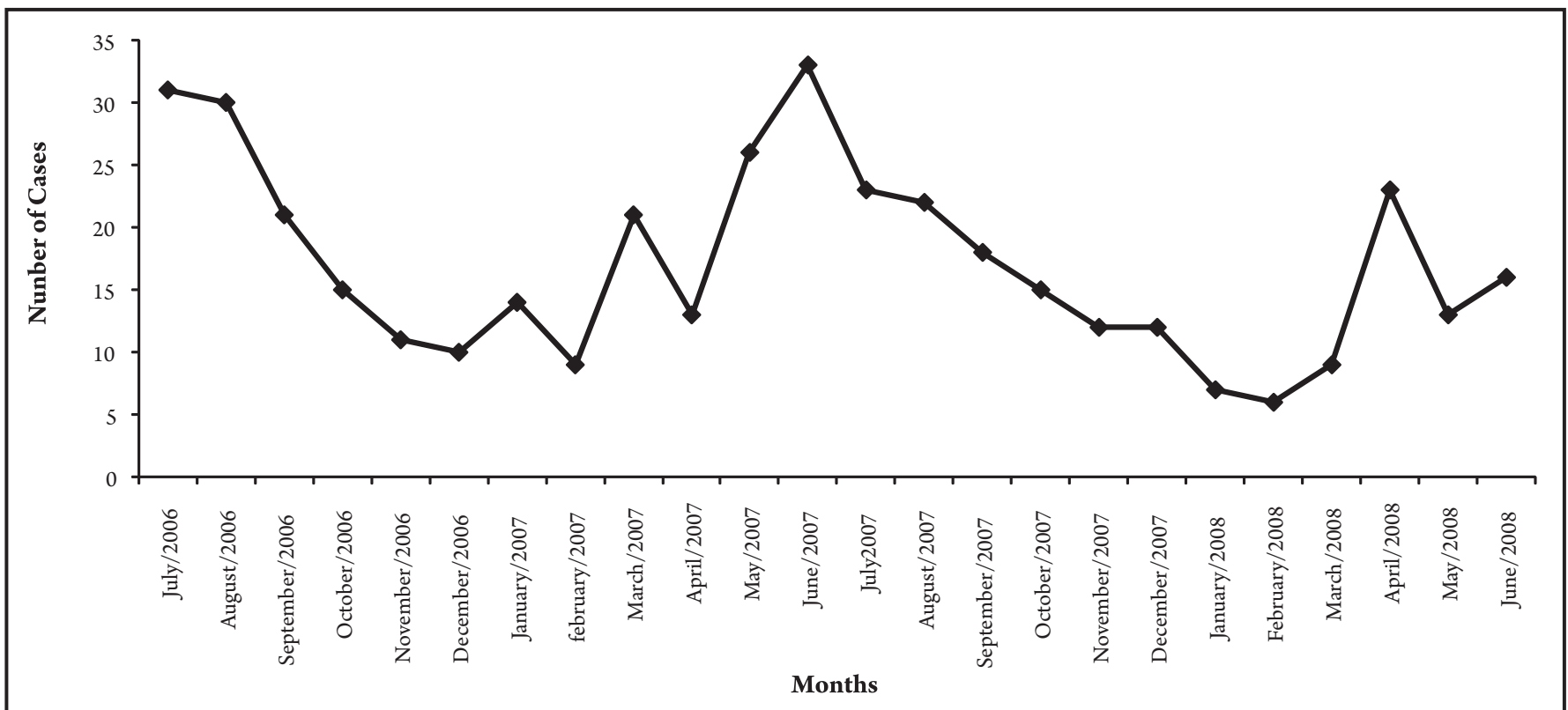

FIGURE 1 - Distribution of accidents involving Bothrops and Bothropoides in the Toxicological Assistance and Information Centers of Paraíba, from July 2006 to June 2008.

TABLE 1 - Profile of accidents involving Bothrops and Bothropoides admitted to the Toxicological Assistance and Information Centers of Paraíba, from July 2006 to June 2008.

\begin{tabular}{|c|c|c|c|c|c|c|c|c|c|}
\hline \multirow[b]{3}{*}{ Variables } & \multicolumn{8}{|c|}{ Severity of accidents n (\%) } & \multirow[b]{3}{*}{$\mathrm{P}$} \\
\hline & \multicolumn{2}{|c|}{ total $(n=410)$} & \multicolumn{2}{|c|}{$\operatorname{mild}(\mathrm{n}=265)$} & \multicolumn{2}{|c|}{ moderate $(n=123)$} & \multicolumn{2}{|c|}{ severe $(n=22)$} & \\
\hline & $\mathrm{n}$ & $\%$ & $\mathrm{n}$ & $\%$ & $\mathrm{n}$ & $\%$ & $\mathrm{n}$ & $\%$ & \\
\hline Anatomical area attacked & & & & & & & & & $0.03(\mathrm{a})$ \\
\hline forearm & 1 & 0.2 & 0 & 0.0 & 1 & 0.8 & 0 & 0.0 & \\
\hline arm & 4 & 1.0 & 4 & 1.5 & 0 & 0.0 & 0 & 0.0 & \\
\hline finger & 41 & 10.0 & 31 & 11.7 & 8 & 6.5 & 2 & 9.1 & \\
\hline toe & 68 & 16.6 & 45 & 17.0 & 19 & 15.4 & 4 & 18.2 & \\
\hline hand & 48 & 11.7 & 34 & 12.8 & 12 & 9.8 & 2 & 9.1 & \\
\hline foot & 216 & 52.7 & 132 & 49.8 & 73 & 59.3 & 11 & 50.0 & \\
\hline leg & 28 & 6.8 & 17 & 6.4 & 9 & 7.3 & 2 & 9.1 & \\
\hline ribs area & 1 & 0.2 & 0 & 0.0 & 0 & 0.0 & 1 & 4.5 & \\
\hline ignored & 3 & 0.7 & 2 & 0.8 & 1 & 0.8 & 0 & 0.0 & \\
\hline Place of occurrence & & & & & & & & & $>0.25(\mathrm{a})$ \\
\hline rural area & 390 & 95.1 & 250 & 94.3 & 120 & 97.6 & 20 & 90.9 & \\
\hline urban area & 20 & 4.9 & 15 & 2.4 & 3 & 2.4 & 2 & 9.1 & \\
\hline Average length of time between the accident and hospital service & & & & & & & & & $<0.01^{* *}$ \\
\hline hours $( \pm \mathrm{DP})$ & 5.8 & 11.3 & 4.3 & 6.5 & 7.7 & 16.9 & 12.3 & 14.4 & \\
\hline Pre-hospital procedure & & & & & & & & & $>0.31^{*}$ \\
\hline adequate & 21 & 5.1 & 17 & 6.4 & 3 & 2.4 & 1 & 4.5 & \\
\hline inadequate & 78 & 19.0 & 45 & 17.0 & 27 & 22.0 & 6 & 27.3 & \\
\hline none & 311 & 75.9 & 203 & 76.6 & 93 & 75.6 & 15 & 68.2 & \\
\hline Notifying Center & & & & & & & & & $0^{*}$ \\
\hline ceatox-CG & 371 & 90.5 & 252 & 95.1 & 103 & 83.7 & 16 & 72.7 & \\
\hline ceatox-JP & 39 & 9.5 & 13 & 4.9 & 20 & 16.3 & 6 & 27.3 & \\
\hline Circumstances & & & & & & & & & $>0.89^{*}$ \\
\hline work & 264 & 64.4 & 167 & 63.0 & 82 & 66,7 & 15 & 68.2 & \\
\hline leisure & 37 & 9.0 & 25 & 9.4 & 11 & 8.9 & 1 & 4.5 & \\
\hline incidental & 109 & 26.6 & 73 & 27.5 & 30 & 24.4 & 6 & 27.3 & \\
\hline
\end{tabular}

* Chi square of linear tendency, ${ }^{* *}$ ANOVA test. 
latex $(20.5 \%)$. The use of alcoholic drinks, fire, garlic, tobacco pastes and cuts followed by sucking on the bite area were also reported.

Regarding severity, the accidents were most frequently classified as mild (64.6\%) and moderate cases (30\%), no statistically significant differences $(\mathrm{p}>0.25)$ were observed between the mild, moderate and severe cases (Table $\mathbf{1}$ ).

The most frequent reactions in the bitten area were pain (95.9\%), edema (87.1\%) and ecchymosis (25.9\%). Regarding systemic reactions, such as headache, bleeding, vomiting, dizziness, hematuria, nausea, myalgia, anuria, oliguria, epistaxis, blurred vision, observation verified that $57.1 \%$ of the patients investigated did not present any systemic reaction (Table 2).

Of the total of 410 patients diagnosed with bothropic and bothropoidic accidents, 2,514 antivenom ampoules were used in 408 patients, and the mean number of ampoules used was $5.2(\mathrm{SD} \pm 2.07)$ in mild cases, $7.5(\mathrm{SD} \pm 2.55)$ in moderate cases and $9.8(\mathrm{SD} \pm 3,44)$ in severe cases.

Antibothropic and antibothropic-crotalic antivenoms were used in $82.7 \%$ and $16.1 \%$ of the cases, respectively. A second serotherapy was used in 91 patients and the mean number of ampoules used was $4.56(\mathrm{SD} \pm 1.74)$ in mild cases, $4.58(\mathrm{SD} \pm 1.70)$ in moderate cases and $9.25(\mathrm{SD} \pm 2.63)$ in severe cases.

All patients received parenteral corticosteroids and/or antihistamines $15 \mathrm{~min}$ before the use of antibothropic or antibothropiccrotalic antivenom. During this research, no reactions were observed before or after treatment with the antivenom.

In $97.1 \%$ of cases, the patients were discharged from hospital, $1.5 \%$ left the hospital by themselves and $1.2 \%$ were transferred to other hospitals. One death was reported, corresponding to $0.2 \%$ lethality. The patients were followed for an average of $60.5 \mathrm{~h}$ in the hospital $(\mathrm{SD} \pm 65.5)$.

TABLE 2 - Local and systemic manifestations induced by accidents involving Bothrops and Bothropoides admitted to the Toxicological Assistance and Information Centers of Paraíba, from July 2006 to June 2008.

\begin{tabular}{|c|c|c|c|c|c|}
\hline \multirow[b]{2}{*}{ Symptom } & \multicolumn{5}{|c|}{ Local symptoms } \\
\hline & $\mathrm{n}$ & $\%$ & Symptom & $\mathrm{n}$ & $\%$ \\
\hline Pain & 393 & 95.9 & Erythema & 29 & 7.1 \\
\hline Edema & 357 & 87.1 & Necrosis & 9 & 2.2 \\
\hline Ecchymosis & 106 & 25.9 & None & 7 & 1.7 \\
\hline \multirow[t]{2}{*}{ Parenthesia } & 30 & 7.3 & Blisters & 5 & 1.2 \\
\hline & \multicolumn{5}{|c|}{ Systemic symptom } \\
\hline Symptom & $\mathrm{n}$ & $\%$ & Symptom & $\mathrm{n}$ & $\%$ \\
\hline None & 234 & 57.1 & Trembling & 1 & 0.2 \\
\hline Cephalea & 96 & 23.4 & Numbness & 1 & 0.2 \\
\hline Bleeding & 43 & 10.5 & Sweating & 1 & 0.2 \\
\hline Emesis & 37 & 9.0 & Renal Insufficiency & 1 & 0.2 \\
\hline Dizziness & 8 & 2.0 & Hypotension & 1 & 0.2 \\
\hline Hematuria & 7 & 1.7 & Hypertension & 1 & 0.2 \\
\hline Nausea & 5 & 1.2 & Hematemesis & 1 & 0.2 \\
\hline Myalgia & 5 & 1.2 & Fever & 1 & 0.2 \\
\hline Anuria & 4 & 1.0 & Dyspnea & 1 & 0.2 \\
\hline Oliguria & 2 & 0.5 & Diplopia & 1 & 0.2 \\
\hline Epistaxis & 2 & 0.5 & Urine color changes & 1 & 0.2 \\
\hline Blurred vision & 1 & 0.2 & & & \\
\hline
\end{tabular}

\section{DISCUSSION}

The occurrence of ophidic accidents in the State of Paraíba presents a mean annual rate of 9.53 accidents/100,000 inhabitants, which is a low index when compared to the national average of 13.9 accidents $/ 100,000$ inhabitants, and higher than the average for the northeast, which is 7.6 accidents $/ 100,000$ inhabitants for $1993^{14}$.

Discussion of this index is of some interest, however the fact that the database of this work was initially developed some years ago means underreporting is likely to be high and data omission in the archives of the notification units of this state is also likely to have occurred ${ }^{2,6}$. We believe the values are much higher, taking into account the variables and considering that the south and southeast regions of Brazil are much better organized concerning the information systems and health services and, therefore, present higher numbers ${ }^{12,14}$.

One fact worth mentioning is that bringing the snake to the hospital remains an uncommon practice in the northeast compared to other Brazilian regions. This practice is extremely important for the identification of the agent of the accident and to determine antivenom use $\mathrm{e}^{11,15-20}$.

Male individuals between 11 and 30 years-old are the most frequent victims of bothropic and bothropoidic accidents in Brazil $^{2,19,21}$, corroborating the results of the present study. Such a high occurrence of bothropic and bothropoidic accidents in male individuals is probably explained by the fact that men work in rural areas more frequently than women, whether for work reasons or leisure ${ }^{20,22}$. Regarding the age range, children in rural communities often work and this may be the reason for classifying the accident as work when reporting the same $\mathrm{e}^{14,15,20,22}$. Furthermore, considering all the variables: place of occurrence and seasonality, agriculture is a risky activity in relation to accidents caused by Bothrops and Bothropoides, such that it is practically an occupational accident ${ }^{2,6,18,19,23}$.

In fact, a correlation exists between seasonality and the occurrence of accidents, making it possible to identify a clear difference in seasonality in several regions of Brazil. However, within the same region, the months with greater occurrence of bothropic and bothropoidic accidents are generally the same in several studies, occurring with higher frequency in months with hot rainy weather, but with some variation according to the region ${ }^{17,19,21,24}$. In Paraíba and in different regions of Brazil, the rainy period is marked by the planting and harvesting season in rural areas, increasing the risk and, consequently, increasing the number of this type of accident during this period ${ }^{11,19,25}$.

The average length of time between an accident and hospital admission is a determining factor in relation to the intensity of the effects of the accident $(p<0.01)$. The length of time between the accident and hospital admission is crucial for satisfactory prognosis of the case ${ }^{17,19}$. In fact, a delay in treatment may generate worsening prognosis, since the antivenom neutralizes the circulating poison and, thus, must be used as soon as possible; i.e., within $6 h^{17,21,26}$.

Observation verified a higher frequency of mild accidents in this study, different from the moderate and severe cases identified in other investigations conducted in several states of Brazil. It is probable that the reasons for this fact include certain differences regarding the venom of several species of Bothrops. It is also possible that relevant differences exist between the venom of the Bothrops and Bothropoides in Brazil ${ }^{5,14,17}$.

However, comparing the data above to previous data from Paraíba ${ }^{22}$, a change was observed concerning the severity of cases, 
since previously, a higher number of moderate accidents were reported, in contrast to the results verified in the present research. This fact can be explained by more efficient/faster hospital admission during the development of this study, making it possible to consider this as a contributing factor to the change in the profile of case evolution, wherein mild cases became more common.

The victims were frequently attacked in the lower limbs, mainly the feet, a point in common with the results of other studies ${ }^{17,23,26,27}$. One possible justification for this is that poisonous snakes prefer to live on the ground and their capacity to defend themselves by attacking someone does not tend to be greater than one third of their length ${ }^{16,22,23}$. The lack of equipment for individual protection (EIP) in rural activities is a crucial factor in the occurrence of such accidents. The use of EIP could prevent 50 to $75 \%$ of bites in such areas s, $23,26,27^{\text {. }}$

A lower number of patients received prehospital care. Among the inadequate procedures, the use of a tourniquet, considered an aggravating procedure, corresponded to a lower number compared to other studies ${ }^{17,19,21,22}$. The rarer use of this procedure could be related to the educational campaigns conducted by the Itinerant Laboratory, a project developed by Paraíba State University, which provides small towns information regarding how to prevent accidents and how to avoid bites by venomous animals. The local press has also contributed by reporting the campaign ${ }^{22,26}$.

The higher index of cases registered at Ceatox-CG, compared to Ceatox-JP is explained by the fact that João Pessoa is located in a coastal forest region, an area with specific vegetation and adequate weather for the natural behavior of several non-venomous snakes, with low reports of Bothrops and Bothropoides in the area. Bothrops and Bothropoides in Paraíba are common in the Caatinga; moreover, the quantity of rural workers, the main victims of these accidents, is lower in the coastal region ${ }^{18,19,28 .}$

Similar to other studies in other regions of the country ${ }^{17}$, observation revealed inadequate use of antivenom, explained by mistaken diagnosis, due to the fact that the initial symptoms can be confused with other types of envenoming, or even due to the lack of a specific antivenom ${ }^{14}$. This information shows the need for qualified human resources to deal with this type of accident, probably by expanding the Toxicological Assistance and Information Centers to other cities in different states of Brazil. This would go some way to solving the problem, since there are only 35 centers distributed throughout Brazil. However, most of the centers are located in the state capitals, while the majority of severe cases occur in small towns.

A modification occurred in the profile regarding the quantity of ampoules used in this type of accident, which is now performed in accordance with the Ministry of Health ${ }^{26}$. This change was not observed in other studies ${ }^{14,17}$. Thus, it is possible to conclude that clinical staff are more aware of the correct procedures now, whereas before they sometimes exaggerated when administering the treatment ${ }^{17,26}$, either due to insufficient knowledge or they were simply insecure concerning the quantity of antivenom needed to neutralize the toxins.

The use of a second dose of antivenom was also observed, as observed by other authors ${ }^{24,29,30}$, raising doubts whether it is necessary to use the second dose. Indication of an additional dose of two ampoules after $12 \mathrm{~h}$ of the serotherapy occurs in certain circumstances: when the coagulation time $(\mathrm{CT})$ remains noncoagulating; or when the patient's condition is not normalized after $24 \mathrm{~h}^{16}$. However, there is no consensus regarding such practices, with the indication of an additional dose recommended only in cases of total blood non-coagulation and the quantity of ampoules established after classification of the poison during admission, generally equal to or lower than the initial dose ${ }^{31}$ used. If it is the possible to diagnose and evaluate how serious the poisonous accident is, use of a second dose of antivenom should not be necessary. However, the lack of an exact diagnosis opens space for such use. It is important to highlight that the antivenom is capable of neutralizing the toxin, not treating signs or symptoms already present in the victim. The antivenom prevents the case from becoming more serious and the continued presence of such signs and symptoms may be used as a parameter for the use of a second dose in some health institutions s $^{17,20,21,32}$.

The local and systemic manifestations observed are in agreement with the national profile, except for the percentage of ecchymosis and blisters ${ }^{33}$, making it possible to infer and compare the variation among toxins produced by the different specimens of Bothrops and Bothropoides snakes and the effects produced ${ }^{14,16,26}$.

All of the treated patients received medication before serotherapy and no undesirable reactions to the serotherapy or pre-medication were mentioned. However, in previous studies, a high level of reactions to the pre-medication was observed ${ }^{17}$, limiting conclusions concerning the efficiency of such drugs or how they work concerning the prophylaxis of reactions to antivenom. Further monitored studies are required to analyze how effective these are at reducing patient risk when in pre-medication treatment and after serotherapy ${ }^{31}$.

In this study, the severity of cases was lower compared to the national average $(0.4 \%)$, and to that of the northeastern region $(0.8 \%)$, in 1990 and in 1993 respectively ${ }^{14,30}$. The result is similar when compared to the average in other states ${ }^{34}$.

The mean number of days patients were in hospital care was high, thus showing that the poisonous accidents continue to represent a public health problem, with the consequent cost to the government/society and also the loss to the economy due to the reduction in labor, since rural workers cannot do their jobs while in treatment. This fact had already been observed in Campina Grande, a town in the State of Paraíba ${ }^{33}$.

This study also shows a decrease in or absence of ignored variables, which were reported by previous studies conducted in Paraíba $^{23}$, making it possible to observe the importance of the work of the Toxicological Assistance and Information Centers in the state.

Analyzing some of the changes investigated and the profile of accidents involving Bothrops and Bothropoides during the study, such as the average time between the accident and hospital admission, the severity of the accidents and the pre-hospital care patients were submitted to, assuming that they were effective, it is possible to justify such changes observing the actions registered in the state through the release of information regarding accidents caused by poisonous animals, through the educational work developed by staff on duty at the Toxicological Assistance and Information Centers during the research and through the contribution of the publication of information in newspapers and on television.

It is expected that the educational work will continue and that it will continue to improve, using the data gathered (including location, place of occurrence and population most frequently affected by the accidents) by this research as a starting point. 


\section{ACKNOWLEDGMENTS}

The authors would like to thank the Centro de Assistência e Informação Toxicológica de João Pessoa (Ceatox-JP), represented by Dr Maria de Fátima Leandro Marques, for providing the data for the development of the research in the Iniciação Científica [Scientific Initiation], from which this work originated.

\section{CONFLICT OF INTEREST}

The authors declare that there is no conflict of interest.

\section{FINANCIAL SUPPORT}

Programa Institucional de Bolsas de Iniciação Cientifica da Universidade Estadual da Paraíba - Conselho Nacional de Pesquisa (PIBIC/UEPB/CNPq) [Grant from the Institutional Program of Scientific Initiation Scholarships of Paraíba State University].

\section{REFERENCES}

1. Sistema de Informação de Agravos de Notificação [Internet]. Relatórios Gerenciais. Acidentes por animais peçonhentos: notificação por tipo de serpente segundo ano. [cited 2009 aug]. Available from: http://www.fiocruz. $\mathrm{br} /$ sinitox/.

2. Albuquerque HN, Fernandes A, Albuquerque ICS. Snakebites in Paraíba, Brazil. J Venom Anim Toxins Incl Trop Dis 2005;11:242-251.

3. França FOS, Málaque CMS. Acidente Botrópico. In: Cardoso JLC, França FOS, Wen FH, Málaque CMS, Haddad V, editors. Animais peçonhentos no Brasil. Biologia, clínica e terapêutica dos acidentes. $2^{\text {th }}$ ed. São Paulo: Sarvier; 2009. p. 72-86.

4. Bérnils RS (org). Brazilian reptiles - List of species [Internet]. Sociedade Brasileira de Herpetologia [cited 2010 aug]. Available from: http://www.sbherpetologia. org.br/

5. Fenwick AM, Gutberlet JRR, Evans JA, Parkinson CL. Morphological and molecular evidence for phylogeny and classification of South American pitvipers, genera Bothrops, Bothriopsis, and Bothrocophias (Serpentes: Viperidae). Zool J Linn Soc 2009; 156:617-640.

6. Albuquerque HN. Perfil clínico-epidemiológico dos acidentes ofídicos notificados no estado da Paraíba. [Dissertação]. [Campina Grande (PB)]: Universidade Estadual da Paraíba e Universidade Federal da Paraíba; 2002. 145p.

7. Melgavarejo AR. Serpentes peçonhentas do Brasil. In: Cardoso JLC, França FOS, Wen FH, Málaque CMS, Haddad V, editors. Animais peçonhentos no Brasil. Biologia, clínica e terapêutica dos acidentes. $2^{\text {th }}$ ed. São Paulo: Sarvier; 2009. p.33-61.

8. Mise YF, Lira-da-Silva RM, Carvalho FM. Envenenamento por serpentes do gênero Bothrops no Estado da Bahia: aspectos epidemiológicos e clínicos. Rev Soc Bras Med Trop 2007; 40:563-573.

9. Jorge MT, Ribeiro LA. Acidentes por serpentes peçonhentas do Brasil. Rev Assoc Med Bras 1990; 36:66-77.

10. Jorge MT, Ribeiro LA. Dose de soro (antiveneno) no tratamento do envenenamento por serpentes do gênero Bothrops. Rev Assoc Med Bras $1997 ; 43: 75-80$

11. Pinho FMO, Oliveira ES, Faleiros F. Acidente ofídico no Estado de Goiás Rev Assoc Med Bras 2004;50:93-99.

12. Sistema de Informação de Agravos de Notificação [Internet]. Relatórios Gerenciais. Acidentes por animais peçonhentos: notificação por tipo de serpente segundo ano. [cited 2009 aug]. Available from: http://www.fiocruz. $\mathrm{br} /$ sinitox/.

13. Sistema Nacional de Informação Toxicológica [Internet]. Casos registrados de Intoxicação Humana por Agente Tóxico (Tabela 04). 2007 - [cited 2009 aug] Available from http://www.fiocruz.br/sinitox/.
14. Instituto Brasileiro de Geografia e Estatística [Internet]. Censo Demográfico Brasileiro 2008. [cited $2008 \mathrm{dec}$ ]. Available from http://www.ibge.gov.br/.

15. Acosta AR, Uzcategui W, Azuaje R, Aguilar I, Girón ME. Análisis clínico y epidemiológico de los accidentes por mordeduras de serpientes del gênero Bothrops en Venezuela. Rev Cubana Med Trop 2000; 52:90-94.

16. Borges CC, Sadahiro M, Santos MC. Aspectos epidemiológicos e clínicos dos acidentes ofídicos ocorridos nos municípios do Estado do Amazonas. Rev Soc Bras Med Trop 1999; 32:637-646.

17. Carvalho MA, Nogueira F. Serpentes da área Urbana de Cuiabá, Mato Grosso: aspectos ecológicos e acidentes ofídicos associados. Cad Saude Publica $1998 ; 14: 753-763$

18. Moreno E, Queiroz-Andrade M,Lira-Da-Silva RM, Tavares-NetoJ. Características clínico-epidemiologicas dos acidentes ofídicos em Rio Branco, Acre. Rev Soc Bras Med Trop 2005; 38:15-21.

19. Oliveira FN, Almeida TD, Fook SML, Rodrigues RL, Albuquerque HN. Estudo dos acidentes ofídicos atendidos e notificados nos Centros de Assistência Toxicológica da Paraíba. Rev Bras Toxic 2007a; 20-22.

20. Oliveira FN, Almeida TD, Fook SM, Morais ICO, Albuquerque HN. Perfi epidemiológico e clinico dos acidentes Botrópicos em Campina Grande - PB, Brasil. Rev Bras Toxic 2007b; 20:21.

21. Rojas CA, Gonçalves MR, Almeida-Santos SM. Epidemiologia dos acidentes ofídicos na região noroeste do Estado de São Paulo, Brasil. Rev Bras Saude Prod An 2007; 8:193-204.

22. Ribeiro LA, Gadia R, Jorge MT. Comparação entre a epidemiologia do acidente a clínica do envenenamento por serpentes do gênero Bothrops, em adultos idosos e não idosos. Rev Soc Bras Med Trop 2008; 41:46-49.

23. Morandi N, Williams J. Snakebite injuries: contributing factors and intentionality of exposure. Wilderness Environ Med 1997; 8:152-155.

24. Albuquerque HN, Costa TBG, Cavalcante MLF. Estudo dos acidentes ofídicos provocados por serpentes do gênero Bothrops no Estado da Paraíba. Rev Biol Cien 2004; 5:1-7.

25. Costa TBG. Estudo dos acidentes ofídicos provocados por serpente do gênero Bothrops no Estado da Paraíba. [Trabalho de conclusão de curso]. [Campina Grande (PB)]: Universidade Estadual da Paraíba; 2004. 120p

26. Feitosa RFG, Melo IMLA, Monteiro HSA. Epidemiologia dos acidentes por serpentes peçonhentas do Estado do Ceará - Brasil. Rev Soc Bras Med Trop 1997; 30:295-301.

27. Ministério da Saúde. Manual de diagnóstico e tratamento de acidentes ofídicos. Fundação Nacional de Saúde, Coordenação de Controle de Zoonoses e animais peçonhentos, Ministério da Saúde, Brasília; 2001.

28. Barraviera B. Estudo clínico dos acidentes ofídicos. Revisão 1993. J Bras Med 1993; 65:209-250.

29. Cardoso JLC, França FOS, Wen FH, Málaque CMS, Haddad V, editors. Animais peçonhentos no Brasil. Biologia, clínica e terapêutica dos acidentes. $2^{\text {th }}$ ed. São Paulo: Sarvier; 2009.

30. Almeida TD, Oliveira FN, Fook SML, Taveira MB, Albuquerque HN. Avaliação de terapêuticas pré-hospitalares com aspectos clínicos de acidentes Botrópicos em Campina Grande-PB, Brasil. Rev Bras Toxic 2007; 20:22.

31. Cupo P, Azevedo-Marques MM, Menezes JB, Hering SE. Reações de hipersensibilidade imediatas após uso intravenoso de soros antivenenos: valor prognóstico dos testes de sensibilidade intradérmicos. Rev Inst Med Trop Sao Paulo 1991; 33:115-122.

32. Wen FH. Soroterapia. In: Cardoso JLC, França FOS, Wen FH, Málaque CMS Haddad V, editors. Animais peçonhentos no Brasil. Biologia, clínica e terapêutica dos acidentes. $2^{\text {th }}$ ed. São Paulo: Sarvier; 2009. p.380-393.

33. Dias-da-Silva W, Guidolin R, Raw I, Higashi HG, Caricati CP, Morais JF et al. Cross-reactivity of horse monovalent antivenoms to venom of ten Bothrops species. Mem Inst Butantan 1989; 51:153-168.

34. Lemos JC, Almeida TD, Fook SML, Paiva AA, Simões MOS. Epidemiologia dos acidentes ofídicos noticiados pelo Centro de Assistência e Informação Toxicológica de Campina Grande (Ceatox-CG), Paraíba. Rev Bras Epidemiol 2009; 12:50-59.

35. Pinho FMO, Pereira ID. Ofidismo. Rev Assoc Med Bras 2001; 47:24-29. 